\title{
Beyond Lawyers: Legal Literacy for the Future
}

\section{Brett Freudenberg*}

Modern life demands literacy in many areas beyond reading and writing. Legal literacy has been argued as an access-to-justice issue and required to ensure a healthy democracy. Further, being able to engage with the economy through a business can be an important avenue to access economic opportunities. However, the world of commerce is underpinned by legal requirements, an understanding of which may assist with compliance behaviour. This article reflects upon the sources of legal literacy, especially in business circumstances, and considers the function of non-lawyer advisers in this area. Evidence suggests that non-lawyer intermediary advisers, such as accountants, play an important role in assisting individuals who are faced with legal problems. Consequently, it is crucial that the legal literacy of these non-lawyer intermediaries is adequate.

\section{INTRODUCTION}

People's legal literacy can be seen as a critical component to ensuring that they are full members of society with the capacity to make a meaningful contribution. Without legal literacy people can become "intimidated and alienated" from the law. ${ }^{1}$ Australia's system of law presumes that citizens are legally literate, as ignorance of the law is not a defence (Ignorantia juris non excusal). ${ }^{2}$ While this presumption can be seen as a necessary fiction to aid with the operation of the legal system, it must be questioned to what extent people realistically have an understanding of the legal system (the "rule of law") and the law that applies to them (the "rules of law"). This understanding refers to both their legal rights as well as their legal obligations. Without such legal literacy people can be disenfranchised and marginalised, as Roznai and Mordechay observed:

... many who encounter legal issues, more often than not, do nothing to find a solution or are unable

to obtain assistance or proper legal advice, due to a lack of information or lack of faith in the system.

Disadvantaged and marginalized populations, in particular, have difficulties in resolving legal problems

or seeking assistance. ${ }^{3}$

To address such a presumption of legal literacy, Roger has argued that it is the government's duty to make "all efforts to inform the public about its laws". ${ }^{4}$ How this is addressed is a multifaceted issue; simply making legal information available via pamphlets or websites is not enough. While others have written about the importance of improving legal literacy of women, those from disadvantaged backgrounds and the disabled, this article considers legal literacy in the context of small business activities.

Being able to engage with the economy through a business can be an important avenue to access economic opportunities, including for those from a disadvantaged background. Small businesses account for $95.9 \%$ of all Australian private sector businesses and contribute over a third of the country's national

\footnotetext{
* Associate Professor, Griffith University.

${ }^{1}$ Canadian Bar Association, "Reading the Legal World: Literacy and Justice in Canada: Report of the Canadian Bar Association Task Force on Legal Literacy" (1992).

${ }^{2}$ Y Roznai and N Mordechay, "Access to Justice 2.0: Access to Legislation and Beyond" (Hebrew University of Jerusalem Legal Studies Research Paper Series No.16-12, 2015) 5.

${ }^{3}$ Roznai and Mordechay, n 2, 25.

${ }^{4}$ A Roger, "Statute Database Publications: How to Keep Statutory Law Current, Historical, Free and Useful - Hong Kong's Experience and Copyright Policies" (2002) 4 UTS Law Review 74, 76-79.
}

Please note that this article is being provided for research purposes and is not to be reproduced in any way. If you refer to the article, please ensure you acknowledge both the publication and publisher appropriately. The citation for the journal is available in the footline of each page.
For information concerning permission to republish material from this journal, either in part or in its entirety, in any medium, please refer to http://sites.thomsonreuters.com.au/ journals/permissions.

For general permission queries, contact LTA.permissions@thomsonreuters.com 
income. ${ }^{5}$ However, small business owners frequently confront a number of issues that can influence their legal literacy. Elliott and Wolfe observed that "the impact of our legal system on commercial activity is substantial", 6 and Cartan and Vilkinas highlighted that "the commercial arena is underpinned, some would say totally dominated by, legal requirements". ${ }^{7}$

It is argued that the need to consider legal literacy has become more acute as disruption and innovation is driving major changes to the economy and the way business is conducted. These changes raise many issues for governments, businesses and individuals to address - some of which are the legal ramifications. For example, the sharing economy has in a short period of time disrupted traditional business models, leaving governments and established businesses grappling with how to legislate and manage these shifts. For individuals the sharing economy has opened up new economic opportunities to participate and raise income. This means that more people are potentially participating in "business"-like activities, and thus need to be aware of the legal implications.

An important part of legal literacy is being able to know when and how to source advice when confronted with a legal problem. To this extent it is important to reflect upon the sources of legal literacy, and consider the role of non-lawyer advisers in assisting with legal problems in business.

This article is organised as follows. The first section provides an overview of the meaning of legal literacy and how it relates to other concepts, as well as its importance and relationship to business. This is followed by a discussion of the research into Australians' legal literacy, and where they are likely to seek advice when encountering a legal problem. This research highlights the importance of nonlawyer intermediaries, in particular accountants. Research about tax law and superannuation literacy is also discussed, as well as how confidence appears to be linked to legal literacy levels. The article then provides reflections about the role of non-lawyer intermediaries and legal literacy, before concluding with suggestions for future research.

\section{LEGAL LITERACY}

There are a number of possible meanings for legal literacy. Roznai and Mordechay have described it as:

... mastering legal discourse at a level that is necessary for conducting a meaningful and active life in a world saturated with a legal culture. In this sense, a legal literate citizen, even if she does not know how to draft legal documents, will know when and how to consult the experts in legal matters, and will be able defend her interests and promote them. ${ }^{8}$

With legal literacy a person can be empowered in matters relating to the law. ${ }^{9}$ This "legal consciousness" can occur when individuals have:

... a basic awareness of the role of the law in everyday solutions. They must have the rudimentary legal knowledge to recognise that their rights or entitlements may have been violated or that they may have a grievance or claim. They must also have sufficient knowledge to realise that there are potential legal solutions, to know when further information or assistance may be necessary and to know where to begin to obtain such assistance. ${ }^{10}$

However, it should be appreciated that legal literacy does not mean that every person is being taught the detailed content of the law, as most are not training to be lawyers. Instead the aim is to ensure that

\footnotetext{
${ }^{5}$ Australian Bureau of Statistics, Counts of Australian Businesses Including Entries and Exits (Jun 2010 to Jun 2014), Cat. No. 8165.0 (ABS, 2015). Count includes non-employing and businesses employing 1-19 employees.

${ }^{6}$ W Elliott and A Wolfe, "The Need for Legal Education for Persons in Business" (1981) 19 American Business Law Journal 153, 175 .

${ }^{7}$ G Cartan and T Vilkinas, "Legal Literacy for Managers: The Role of the Educator" (1990) 24(3) The Law Teacher 246, 246.

${ }^{8}$ Roznai and Mordechay, n 2, 25.

${ }^{9}$ Roznai and Mordechay, n 2, 25.

${ }^{10}$ C Coumarelos et al, "Legal Australia-Wide Survey: Legal Need in Australia”, Access to Justice and Legal Needs Vol 7 (Law and Justice Foundation of NSW, 2012) 29.
} 
people have a fundamental knowledge of the legal system, their legal rights and obligations, as well as where to source assistance when faced with legal problems.

Such legal literacy can influence a person's perceptions about the legal system, including their ideas about its benefits and fairness, and can lead to moral obligations in respect of the system of law. In this way, people's understanding of the "rules of law" may assist their knowledge and appreciation of the "rule of law". Braithwaite has argued about motivational postures in a "Wheel of Social Alignment", were compliance is influenced by: (i) technical knowledge; (ii) perceptions (of benefits, of fairness, of moral obligations); and (iii) the other. ${ }^{11}$

A type of literacy that has gained increased attention recently is "financial literacy", as individuals face a myriad of decisions that are critical to their financial wellbeing. ${ }^{12}$ Financial literacy has been defined as "the ability to make informed judgements and to make effective decisions regarding the use and management of money". ${ }^{13}$ However, Chardon has argued that the notion of financial literacy needs to be expanded to include tax law literacy given its influence on investment outcomes. ${ }^{14}$

Similar to financial literacy, the notion of legal literacy is not just about knowledge but also capability and confidence. Legal capability refers to the "characteristics or competencies (knowledge, skills, psychological, resources)" of a person to allow them to effectively resolve legal issues that they may confront. ${ }^{15}$ It is these personal characteristics that can be fundamental indicia to putting legal knowledge into action:

[I]ncreasing legal knowledge is often a vital and necessary ingredient of promoting access to justice, it may not, in and of itself, be sufficient. Motivation, emotional resilience, a belief that the steps taken will make a difference, skills to follow the steps suggested, and time and resources to act, are just some of the other requirements. ${ }^{16}$

While it is acknowledged that legal capability is essential, this article will use the term "legal literacy" as including the notion of legal capability.

The idea of improved legal literacy is profoundly associated with the concept of meaningful access to justice, and has included educational programs, access to legislation and the drive for plain language for legal documents. For example, in Australia there are Community Legal Education programs, ${ }^{17}$ which can be the responsibility of government agencies, ${ }^{18}$ as well as access to legislation initiatives that have harnessed the internet, such as the Australasian Legal Information Institute (AustLII) established in $1995 .{ }^{19}$ The use of plain language in legalisation has been driven by the Office of Parliamentary Counsel and has seen, for example, the redrafting of Australia's tax legislation (although this has stalled due to budget cuts). ${ }^{20}$

\footnotetext{
${ }^{11}$ V Braithwaite, “Tax and Democracy: Bygone Ideas or Time for Reinvention?" (Presentation at the $29^{\text {th }}$ Australasian Tax Teachers Association Conference, Masterton, Victoria University of Wellington, 2017).

${ }^{12}$ Australian Securities and Investments Commission, "Report 230: Financial Literacy and Behavioural Change" (2011) < www. financialliteracy.gov.au/media/218309/ financial-literacy-and-behavioural-change.pdf $>$.

${ }^{13}$ Australian Securities and Investments Commission, $\mathrm{n} 12$.

${ }^{14}$ T Chardon, "Weathering the Storm: Tax as a Component of Financial Capability" (2011) 5(2) Australasian Accounting Business and Finance Journal 53.

${ }^{15} \mathrm{~N}$ Balmer et al, Knowledge, Capability and the Experience of Rights Problems (Plenet, 2010).

${ }^{16} \mathrm{~S}$ Forell and H McDonald, "Beyond Great Expectations: Modest, Meaningful and Measurable Community Legal Education and Information" (Justice Issues Paper 21, Law and Justice Foundation of NSW, 2015) 6.

${ }^{17}$ Roznai and Mordechay, n 2, 23.

${ }^{18}$ For example, legislation establishing Legal Aid Commissions in Australia in the 1970s specified that education is one of its functions (see, eg Legal Aid Commission Act 1979 (NSW)).

${ }^{19}$ Roznai and Mordechay, n 2.

${ }^{20}$ A Sawyer, "Rewriting Tax Legislation - Can Polishing Silver Really Turn it Into Gold?" (2013) 15(1) Journal of Australian Taxation 1.
} 


\section{The Importance of Legal Literacy}

The arguments for the importance of legal literacy have focused on its relationship to social contract theory, knowing your rights and obligations, and thereby minimising (or avoiding) problems. Other reasons include notions of social justice, as well as being empowered to demand justice. Kumar and Singla described legal literacy as "one of the keys of success, prosperity, peace and popularity of a country", ${ }^{21}$ and Leston-Bandeira equated it to a "civic virtue or even as an inherent feature of the democratic society itself". 22

In terms of social contract it has been argued that legal literacy "can contribute to the development of the fundamental values of the legal system in which human dignity, decency, justice, trust, tolerance and restraint promote the rule of law". ${ }^{23}$ Through this, legal literacy may lead to a respect for the law that otherwise could be lacking, as it helps "people understand it and encouraging them to engage with the legal system". ${ }^{24}$

Also, having a greater understanding of the law can enable individuals to "identify, understand and enforce their legal rights". ${ }^{25}$ This is important as without legal literacy people can fail to identify how the law can be used to protect, leading to massive legal exclusion. ${ }^{26}$ It should be acknowledged that having greater legal literacy could also enable people to take advantage of the legal system. For example, it could lead to individuals being able to take advantage of the tax law arbitrages (depending upon the legal business structure used) as well as asset protection. Hence, while this improved legal literacy may aid the "individual", it could be seen as a cost to "society". It is not the purpose of this article to question the morality of the current status of the law, but to suggest that if citizens have greater legal literacy then they are more able to engage in debate about whether the laws are appropriate or not.

Further, legal literacy can lead to individuals having a better understanding of their legal obligations, and thereby the potential to avoid legal problems. As Haapio stated: "[L]egal knowledge is most valuable when it is used before things go wrong ... everyone's resources are saved". ${ }^{27}$ Such knowledge may reduce crime and antisocial behaviour. ${ }^{28}$ Ignorance can cause people to be unnecessarily involved with the legal system, which can create costs to the individual and society. ${ }^{29}$ In contrast, legal literacy can lead people to take preventative action that "avoids escalation and crises". ${ }^{30}$ Even when a dispute arises, being legally literate may open avenues to avoid court proceedings "leading to outcomes that are quicker, less stressful and less costly for both sides in a dispute". ${ }^{31}$

Coumarelos et al have argued that people who ignore their legal problems can achieve poor outcomes. ${ }^{32} \mathrm{~A}$ lack of legal literacy may allow corruption in society to flourish as the legal system is not used to uphold the rule of law. ${ }^{33}$ Further, legal illiteracy may leave people vulnerable to be taken

\footnotetext{
${ }^{21}$ M Kumar and N Singla, "Role of Legal Fraternity in Imparting Legal Literacy: A Study in Indian Context" (2012) 2(3) International Journal of Physical and Social Sciences 124, 125.

${ }^{22}$ C Leston-Bandeira, "Studying the Relationship between Parliament and Citizens" (2012) 18(3-4) The Journal of Legislative Studies 265, 269.

${ }^{23}$ Roznai and Mordechay, n 2, 26.

${ }^{24}$ Public Legal Education and Support (PLEAS) Task Force, Developing Capable Citizens: The Role of Public Legal Education (Russell Press, 2007) 10

${ }^{25}$ Forell and McDonald, n 16, 1.

${ }^{26}$ PLEAS Task Force, n 24.

${ }^{27}$ H Haapio, "Legal Literacy: Helping Clients to Help Themselves" (2002-2003) 21 Preventative Law Reporter 7, 12.

${ }^{28}$ PLEAS Task Force, n 24.

${ }^{29}$ W Cassidy and P Pitsula, "Forging a New Pathway: Learning from Experience and Research to Shape Practice in Public Legal Education Efforts in Canada" (2005) 15(2) Education Law Journal 113.

${ }^{30}$ PLEAS Task Force, n 24, 9.

${ }^{31}$ PLEAS Task Force, n 24, 9.

${ }^{32}$ Coumarelos et al, n 10, 29.

${ }^{33}$ Kumar and Singla, n 21.
} 
advantage of in terms of scams, whether it is initially entering into the scam or later in-action to enforce their rights. For example, purported tax law advantages are often used as incentives or sales tactics for many investments and particularly for risky investment scams. ${ }^{34}$

These arguments are especially acute if one considers that legal illiteracy can be particularly adverse to disadvantaged groups and women:

For certain disadvantaged groups, access to institutional legal procedure is not optional simple due to the lack of information that will allow them to identify a legal issue, the apprehension to act against more powerful institutional players, or scepticism with regard to the possibilities that the legal system has to offer ... Thus knowledge and information are essential for accessibility. ${ }^{35}$

Macklin argued that women's legal literacy, in the form of knowing their rights under international and domestic law, is "critical to supporting and enhancing women's agency". ${ }^{36}$ With this knowledge and confidence people can be active agents in their society; they can "act upon the law to make it relevant, [and] know how to use and direct the law to forge new and more adequate forms of social organization and interaction". ${ }^{37}$ In this way, legally literate people can "participate in creating their society". ${ }^{38}$

\section{Business and Legal Literacy}

In neoliberal society the ability to access and participate in the economy in a meaningful way through business can be an important vehicle for social justice, particularly for new immigrants, women and those from low socioeconomic backgrounds. For example, Vinson maintained that paid work is the most effective way to reduce poverty, entrenched disadvantage and social exclusion, ${ }^{39}$ and Condon's research demonstrated that working from home offers the flexibility valued by mothers. ${ }^{40}$ In $2004,67 \%$ of small Australian businesses were based at home, ${ }^{41}$ and today approximately one-third of business owners/managers are women. ${ }^{42}$ It is important to reflect how legal literacy, and avenues that people use to enhance it, could influence access to economic opportunities. The United Nations and the World Bank are currently examining "entry barriers" in various countries to assess how small business owners and entrepreneurs are able to become familiar with regulation..$^{43}$ There is growing acknowledgement that access to and understanding of government regulation can decrease employment costs and assist the profitability of small businesses. ${ }^{44}$

A lack of legal literacy could also affect business decisions, as it may cause "stress and anxiety when making decisions". ${ }^{45}$ In contrast, Haapio highlighted that "a legally literate workforce can take better

${ }^{34}$ T Chardon, B Freudenberg and M Brimble, "Tax Literacy in Australia: Not Knowing Your Deduction from Your Offset" (2016) 31(2) Australian Tax Forum 321.

${ }^{35}$ Roznai and Mordechay, n 2, 28.

${ }^{36}$ A Macklin, "Legal Aspects of Conflict-Induced Migration by Women” (2008) 16(31) Reproductive Health Matters 22, 30.

${ }^{37}$ M Schuler and S Kadirgamar-Rajasingham, "Introduction" in M Schuler and S Kadirgamar-Rajasingham (eds), Legal Literacy: A Tool for Women's Empowerment (UN Development Fund for Women, 1992) 1.

${ }^{38}$ Schuler and Kadirgamar-Rajasingham, n 37, 6.

${ }^{39}$ T Vinson, Dropping Off the Edge: The Distribution of Disadvantage in Australia (Jesuit Social Services/Catholic Social Services, 2007).

${ }^{40} \mathrm{~S}$ Condon, Sole Mothers, Work/Life Balance and Wellbeing: Understanding Constraints and Finding Pathways to Empowerment (PhD thesis, Griffith University, 2008).

${ }^{41}$ Australian Bureau of Statistics, Measures of Australia's Progress: Wellbeing (ABS, 2004).

${ }^{42}$ Australian Small Business and Family Enterprise Ombudsman, "Small Business Counts: Small Business in the Australian Economy" (2017) 34. In terms of part-time owner/managers, approximately $70 \%$ are women.

${ }^{43}$ Roznai and Mordechay, n 2.

${ }^{44}$ J Valbe and N Castellas, "What's the Cost of e-Access to Legal Information? A Composite Indicator", Doing Business (World Bank, 2014).

${ }^{45}$ T Davies, "The Worrisome State of Legal Literacy Among Teachers and Administrators" (2009) 2(1) Canadian Journal for New Scholars in Education 1, 4. 
care of the deals it makes, and avoid unnecessary problems". ${ }^{46}$ In this way, legal literacy can be seen as a "valuable corporate asset". ${ }^{47}$ Having greater legal literacy when operating a business may improve compliance as there is "a better realization of rights and fulfilment of obligations" ${ }^{48}$ Cartan and Vilkinas observed that most (if not all) business decisions can have legal implications, thus highlighting the importance of legal literacy for this sector. ${ }^{49}$ Of course, the scope of legal literacy for business is likely to be different to other sectors, as Cartan and Vilkinas stated:

Almost any decision taken by a manager will or could have some legal dimension ... consider the following everyday managerial activities: advertising, hiring staff, purchasing raw material, selling goods, writing cheques, reprimanding employees, paying taxes, etc. The legal web embraces all these operations. ${ }^{50}$

A lack of legal literacy may adversely affect people's professional behaviour. In regards to professional teaching staff and administrators, Zirkel noted that poor legal knowledge could alter behaviours, which could lead to defensive teaching with practices not shaped by pedagogical notions but from a fear of being sued ${ }^{51}$ - a fear that is largely misplaced, as Stewart suggested, the "cynical beliefs many principals hold regarding liability are unrealistic". ${ }^{52}$ In a similar vein, concerns have been raised about professionals in the medical industry - "the physician who lacks the relevant legal knowledge is often practicing in fear". ${ }^{33}$ This could then result in medical professionals going to extreme measures, including recommending unnecessary testing or hospitalisation, in an attempt to avoid any legal problems. ${ }^{54}$ This concern led Preston-Shoot and McKimm to argue for a change to the curriculum taught to medical and social workers with a need for greater legal education ${ }^{55}$ to enable them to work more effectively.

The effect of legal literacy on behaviour has been raised a number of times. For example, McKerchar's research suggested that non-compliant behaviour by taxpayers was not necessarily deliberate, and that a lack of tax law literacy meant that they were likely to be unintentionally non-compliant. ${ }^{56} \mathrm{McKerchar}$ found "evidence of a high commitment to compliance" but a lack of tax law literacy impeded a full realisation of this ${ }^{57}$ Such legal illiteracy may mean that people miss out on government concessions or benefits provided through the tax system. Programs have been set up to address this by improving legal literacy through community service centres to enable people to access such benefits. ${ }^{58}$ Research has also demonstrated that education and tax law literacy may have a positive impact on compliance. ${ }^{59}$ Taxpayers

\footnotetext{
${ }^{46}$ Haapio, n 27, 13.

${ }^{47}$ Haapio, n 27, 14.

${ }^{48}$ Roznai and Mordechay, n 2, 26.

${ }^{49}$ Cartan and Vilkinas, $n 7$.

${ }^{50}$ Cartan and Vilkinas, n 7, 246.

${ }^{51}$ P Zirkel, "Paralyzing Fear? Avoiding Distorted Assessments of the Effect of Law on Education" (2006) 35(4) Journal of Law and Education 461.

${ }^{52}$ D Stewart, "Legalisation of Education: Implications for Principals' Professional Knowledge" (1998) 36(2) Journal of Educational Administration 129, 130 .

${ }^{53}$ R Wong and U Balasingam, "Teaching Medical Law in Medical Education” (2013) 12 Journal of Academic Ethics 121, 127.

${ }^{54}$ Wong and Balasingam, n 53.

${ }^{55}$ M Preston-Shoot and J McKimm, "Exploring UK Medical and Social Work Students' Legal Literacy: Comparisons, Contrasts and Implications" (2013) 21(3) Health and Social Care in the Community 271

${ }^{56} \mathrm{M}$ McKerchar, The Impact of Complexity Upon Unintentional Non-Compliance for Australian Personal Income Taxpayers (Doctoral Dissertation, University of New South Wales, 2002).

${ }^{57}$ McKerchar, n 56, 298.

${ }^{58}$ Canadian Government, "Why Financial Capability Matters: Synthesis Report of Canadians and Their Money: A National Symposium on Financial Capability" (2006) 6.

${ }^{59}$ P Nzioki and R Osebe, "An Analysis of Factors Affecting Tax Compliance in the Real Estate Sector in Kenya: A Case Study of Real Estate Owners in Nakuru Town, Kenya" (2014) 5(11) Research Journal of Finance and Accounting 1.
} 
consider that if they had improved tax law literacy their compliance would improve; ${ }^{60}$ increased tax law literacy may improve taxpayers' attitudes toward the tax system, ${ }^{61}$ and thereby have a positive influence on willingness to be compliant. ${ }^{62}$ Of course whether their behaviour would change is questionable, but it could assist those who do want to comply.

More recently, Mihaylov et al found that legal literacy in regards to Self-Managed Superannuation Fund (SMSF) regulation is likely to be significantly higher for those trustees of compliant SMSFs compared to non-compliant ones.$^{63}$ Consequently, it may be that higher levels of legal literacy may lead to improved compliance behaviour; although other factors may influence this relationship.

Conducting a small business raises a number of legal literacy issues. Small businesses are an integral part of the Australian economy, accounting for $95.9 \%$ of all private sector businesses ${ }^{64}$ and contributing $34 \%$ of total gross value added to the economy ${ }^{65}$ There are over 1,062,000 individuals acting as sole traders with micro-sized businesses, and another 3,000 with small-sized businesses ${ }^{66}$ There are another $1,290,000$ micro and small-sized businesses conducted through corporations, partnerships and trusts. ${ }^{67}$ It is estimated that small businesses employ 4.8 million people, representing $45.7 \%$ of all private sector employees. ${ }^{68}$ However, small businesses can face a number of issues, including financial constraints, compliance costs and restricted management capacity. ${ }^{69}$

The number of individuals in business (or business-like ventures) is likely to expand with the rise of the sharing economy, which has attracted many individuals who previously were not "in business" and who may now be regarded as such with potential tax and regulatory consequences. Oei and Ring have observed that the sharing economy and the legal implications are far from clear and even with legal literacy "taxpayers engaged in sharing may nonetheless find it difficult to apply the rules and to maintain the required documentation"..$^{70}$ An example of the complexity of issues that can arise is illustrated by trying to determine the legal relationships of Uber drivers and the Uber sharing platform. For example, this issue is pivotal to a Perth Uber driver who has his contract terminated. His legal status with Uber is critical, because if an Uber driver is an "employee" then the Fair Work provisions are relevant; if instead he is an "independent contractor" then the Federal Court could consider whether it was an unfair contract. ${ }^{71}$ Also, after some uncertainty, recently the GST status of Uber drivers as "taxis" was judicially determined.$^{72}$ Regardless of this uncertainty, sharing platforms could see an increase in the number of people in "business"-like activities.

\footnotetext{
${ }^{60}$ N Saad, “Tax Knowledge, Tax Complexity and Tax Compliance: Taxpayers' View” (2014) 109 Procedia-Social and Behavioral Sciences 1069.

${ }^{61}$ K Eriksen and L Fallan, "Tax Knowledge and Attitudes Towards Taxation: A Report on a Quasi-Experiment" (1996) 17(3) Journal of Economic Psychology 387.

${ }^{62}$ N Islamiah Kamil, "The Effect of Taxpayer Awareness, Knowledge, Tax Penalties and Tax Authorities Services on the Tax Compliance: Survey on the Individual Taxpayer at Jadobdetabek and Bandung" (2015) 6(2) Research Journal of Finance and Accounting 104.

${ }^{63}$ G Mihaylov et al, "Tax Compliance Behaviour in Australian Self-Managed Superannuation Funds" (2015) 13(3) eJournal of Tax Research 740.

${ }^{64}$ Australian Bureau of Statistics, n 5.

${ }^{65}$ Australian Bureau of Statistics, Australian Industry, 2013-14. Cat. No. 8155.0 (ABS, 2015).

${ }^{66}$ Australian Taxation Office, Taxation Statistics 2013 (ABS, 2015).

${ }^{67}$ Australian Taxation Office, $\mathrm{n} 66$.

${ }^{68}$ Australian Bureau of Statistics, $\mathrm{n} 65$.

${ }^{69}$ M Belle Isle and B Freudenberg, "Calm Waters: GST and Cash Flow Stability for Small Businesses in Australia" (2015) 13(2) eJournal of Tax Research 492.

${ }^{70}$ S-Y Oei and D Ring, “Can Sharing Be Taxed?” (2016) 93(4) Washington University Law Review 989, 1053.

${ }^{71}$ J Riley, "Sacked Uber Driver Case Shows Driver Vulnerability Under the Law”, The Conversation, 20 May 2016.

${ }^{72}$ Uber BV v Commissioner of Taxation [2017] FCA 110.
} 
Another Australian study has sought to measure the specific area of tax law literacy (part of Chardon's research arguing that tax law literacy should be part of financial literacy).${ }^{73}$ Chardon et al found that $19 \%$ of Australians had tax literacy scores classified as either "poor" or "low" ${ }^{74}$ However, when taking the mean tax law literacy scores as a percentage of the maximum score, it was found that the mean score fell at $52 \%$ of the maximum score. When this mean tax law literacy score is compared against the 2008 ANZ financial literacy survey score of $71.3 \%$, this indicates that while Australians are broadly tax literate they are less literate compared to financial issues more broadly. The demographics at risk of lower tax law literacy were the young, the less educated, the unemployed and low-income earners. ${ }^{75}$ However, it was found that self-employed people (ie people running their own business) had the highest tax law literacy scores. This suggests that the extra responsibilities of running a business improves a person's tax law literacy; although it is not clear as to whether this improved literacy is sufficient to conduct a business.

Other research demonstrates that a lack of knowledge and confidence about the superannuation law system can be part of the reason that employees do not act when their superannuation guarantee is underpaid. A 2013 survey demonstrated a number of barriers to employees lodging complaints in regard to an underpaid superannuation guarantee, including: the fear of losing their job (42\%); angering their employer (29\%); lack of knowledge of how to go about it (28\%); and never getting around to it (28\%). ${ }^{76}$ This research indicated a large deficiency in employees' legal literacy in terms of superannuation with $49 \%$ of employees not particularly knowledgeable, which could explain why nearly one-third (28\%) did not know how to report underpaid superannuation. ${ }^{77}$ Freudenberg and Sargent postulated that this lack of legal literacy towards superannuation can mean that employees do not have the knowledge to monitor their superannuation guarantee, nor know what to do in circumstances of underpayment. ${ }^{78}$ This illiteracy also has social implications as research demonstrates that those more at risk of being subject to non-compliance are generally those with less knowledge, which includes women, 18-24 year olds, those based in regional Australia, casual employees, the unemployed and those working for micro-sized businesses. ${ }^{79}$ Such findings emphasise the importance of legal literacy, especially for certain at-risk demographics.

As discussed above, the notion of legal literacy is not just about knowledge but also confidence, as this may be a large component to enforcing one's legal rights. Financial literacy research has demonstrated that there can be over-confidence, particularly in relation to basic financial concepts and investment decisions.$^{80}$ In contrast, with legal literacy there appears to be greater alignment between knowledge and confidence (and at times under-confidence) - ie if a person is confident about their legal knowledge then this is likely to be aligned with the person's actual knowledge, or indicate that their knowledge is greater.

Chardon et al found that over-confidence is not common in relation to tax and superannuation law. ${ }^{81}$ Generally, participants were largely under-confident and there were almost no instances of low selfassessed confidence and high tax literacy scores. Part of the reason for this greater alignment could be an awareness of penalties for incorrect application of tax law and therefore people are more cognitive of their actual knowledge. ${ }^{82}$

\footnotetext{
${ }^{73}$ Chardon, $\mathrm{n} 14$.

${ }^{74}$ Chardon, Freudenberg and Brimble, n 34.

${ }^{75}$ Chardon, Freudenberg and Brimble, n 34.

${ }^{76}$ B Tan and F Pedic, Superannuation Guarantee Research (GfK Australia Pty Ltd, 2013) 37.

${ }^{77}$ Tan and Pedic, n 76, 3.

${ }^{78}$ B Freudenberg and S Sargent, "Not So Guaranteed: Superannuation Guarantee and Australian Small Businesses” (2015) 30(1) Australian Tax Forum 89.

${ }^{79}$ Tan and Pedic, n 76, 18.

${ }^{80}$ Financial Literacy Foundation, "Financial literacy - Australians Understanding Money" (Australian Government, 2007) < $\underline{w w w . ~}$ financialliteracy.gov.au/media/209293/australians-understanding-money.pdf>; G Gallery and N Gallery, "Rethinking Financial Literacy in the Aftermath of the Global Financial Crisis" (2010) 19 Griffith Law Review 130.

${ }^{81}$ T Chardon, B Freudenberg and M Brimble, "Are Australians Under or Over Confident When it Comes to Tax Literacy, and Why Does It Matter?" (2016) 14(3) eJournal of Tax Research 650.

${ }^{82}$ Chardon, Freudenberg and Brimble, n 81.
} 
It was found that the self-employed (those running a business) had the highest tax confidence, which was consistent with their greater tax literacy.$^{83}$ In contrast, lower confidence was more likely to be found in females, younger age groups and those on lower incomes ${ }^{84}$ Also, lower confidence in relation to taxation and superannuation law issues was likely to be found in those with less participation in the paid workforce (such as full-time students or those not in paid work) and those with lower education levels. ${ }^{85}$

In terms of trustees of SMSFs, self-reported legal literacy has been found to have a positive correlation to knowledge scores. ${ }^{86}$ Similarly, the level of legal training also had a positive correlation. Participants' level of interest was negatively correlated (ie those who knew least were most interested in knowing more). ${ }^{87}$

Overall, legal literacy in relation to business operations is important as it allows people to know their rights and obligations, and thus to be proactive in minimising their legal problems. In terms of tax law, evidence suggests that business obligations lead to greater tax law literacy when compared to others in the population.

However, when it comes to legal literacy in terms of business operations what role do advisers play? In particular, which advisors are likely to be sought out when a small business is faced with a legal problem? While it may be assumed that lawyers are the advisors first sought it is argued that non-lawyer intermediaries are likely to play a large role in assisting with the legal literacy of small businesses.

\section{RESEARCH INTO LEGAL LITERACY}

A component of legal literacy is knowing where and how to seek advice when faced with a legal problem. ${ }^{88}$ While a Canadian national study found that "people almost exclusively link the need for legal information and/or assistance with the traditional gatekeepers of the justice system - lawyers" ${ }^{89}$ the evidence from Australia demonstrates that this is not the case and that non-lawyer intermediaries play an important role.

The 2012 LAW Survey involving 20,716 interviews across Australia is the largest legal needs survey to date conducted anywhere in the world..$^{90}$ The LAW Survey highlighted a number of things. As background, it found that consumer, crime, housing and government were the most prevalent legal problems encountered. ${ }^{91}$ However, it appeared that a minority of participants (9\%) accounted for the majority of reported legal problems $(65 \%) .{ }^{92}$ Also, there appeared to be a relationship with age, as those in the oldest age bracket (65 years or over) had significantly lower prevalence of legal problems. ${ }^{93}$ The type of legal problem also varied with a person's life stage, as "accidents, crime, personal injury and rights problems peaked between 15 and 24 years of age, and credit/debt and family problems peaked between 25 and 44 years of age". ${ }^{4}$

The groups that had increased prevalence of legal problems were those with a disability, followed by Indigenous respondents, the unemployed, single parents, those living in disadvantaged housing and

\footnotetext{
${ }^{83}$ Chardon, Freudenberg and Brimble, n 81.

${ }^{84}$ Chardon, Freudenberg and Brimble, n 81.

${ }^{85}$ Chardon, Freudenberg and Brimble, n 81.

${ }^{86}$ Mihaylov et al, n 63.

${ }^{87}$ Mihaylov et al, n 63.

${ }^{88}$ Coumarelos et al, n 10.

${ }^{89}$ Cassidy and Pitsula, n 29, 116.

${ }^{90}$ Coumarelos et al, n 10 , iv.

${ }^{91}$ Coumarelos et al, n 10.

${ }^{92}$ Coumarelos et al, $\mathrm{n} 10$, xiv.

${ }^{93}$ Coumarelos et al, n $10, x v$.

${ }^{94}$ Coumarelos et al, n $10, \mathrm{xv}$.
} 
those whose main income was government payments..$^{95}$ The legal problems resulted in the following adverse consequences: income loss or financial strain (29\%); stress-related illness (20\%) and physical ill health (19\%); relationship breakdown (10\%); and moving home $(5 \%) .{ }^{96}$

In considering the sources of advice, when Australians are confronted with a legal problem it becomes apparent the minimal role that lawyers initially play. Approximately one-half of the total (49$53 \%$ ) sought any advice at all, with one-third (27-32\%) handling their legal problem without any advice and approximately $20 \%(16-21 \%)$ taking no action at all. ${ }^{97}$

In terms of ignoring the legal problems the reasons given were diverse, including: that it would take too long to resolve the problem (35\%); the respondent had bigger problems (31\%); it would be too stressful (30\%); it would cost too much (27\%); the respondent didn't know what to do (21\%); or it would damage the respondent's relationship with the other side (13\%). ${ }^{98}$

In the circumstances that advice was sought, only about one-fifth (21.3\%) of advice was sought from private lawyers, and of that $4.4 \%$ was a friend or relative that happened to be a lawyer. ${ }^{99}$ Overall, given that advice was sought in only $50 \%$ of cases, people sought advice from a legal adviser for only $16 \%$ of all legal problems..$^{100}$

In close to $70 \%(69.7 \%)$ of the problems where advice was sought respondents used non-legal intermediary advisers, with only $30.3 \%$ of respondents seeking advice from a legal adviser. ${ }^{101}$ Non-legal intermediary advisers included:

1. government adviser (eg police, government department and/or local council) (38.8\%);

2. health or welfare adviser (eg doctors, psychologist/welfare counsellor) (27.2\%);

3. financial adviser (eg insurance company, accountant or financial planner) (22.2\%);

4. other (eg employer, school, non-legal community organisation) (17.1\%);

5. dispute/complaint-handling adviser (eg ombudsman) (8.1\%); and

6. trade or professional association (eg trade onion or professional association) (7.6\%). ${ }^{102}$

This highlights that non-lawyer intermediaries appear to be critical as a first point of contact for people confronted with a legal problem. In regards to whether advisers appeared relevant to the legal problem encountered, analysis determined that the first adviser was generally appropriate ${ }^{103}$ For example, the top six areas that financial advisers were consulted in regards to legal problems were: accidents (76.3\%); credit/debt (44.7\%); money (35.5\%); crime (20.5\%); consumer (20.3\%); and government $(20.1 \%)$.

In terms of problem severity and the type of adviser initially consulted, the top five advisers who assisted with substantial problems that impacted on everyday lives were:

1. not-for-profit legal services $(79.1 \%)$;

2. health/welfare advisers $(75.4 \%)$;

3. private lawyers $(73.4 \%)$;

4. government departments $(69.2 \%)$; and

5. accountants $(66.5 \%) .{ }^{104}$

\footnotetext{
${ }^{95}$ Coumarelos et al, n 10, xv.

${ }^{96}$ Coumarelos et al, $\mathrm{n} 10$, xvi.

${ }^{97}$ Coumarelos et al, n 10, xvi.

${ }^{98}$ Coumarelos et al, n 10, xvii.

${ }^{99}$ Coumarelos et al, n 10, 112.

${ }^{100}$ Coumarelos et al, n 10, xvii.

${ }^{101}$ Coumarelos et al, n 10, 111. Note "private lawyers" are only one of the possible sources of legal advice, with other sources including court services and legal aid.

102 This is based on all of the advisers used for each problem (and thus includes multiple advisers for some problems: see Coumarelos et al, n 10, 112-113, Table 6.2).

${ }^{103}$ Coumarelos et al, n 10, 113-114, Table 6.3.

${ }^{104}$ Coumarelos et al, n 10, 116.
} 
This would indicate that accountants are regularly consulted in serious situations. According to this research, when people were confronted with a legal problem, they did not necessarily get legal help from their main adviser. ${ }^{105}$ However, many did seek legal advice. It was found that the percentage of problems where people did seek legal help from their main adviser was: $92.2 \%$ from legal adviser;

1. $82.3 \%$ from trade or professional association;

2. $81.1 \%$ from dispute/complaint handling adviser;

3. $61.0 \%$ from government adviser;

4. $60.2 \%$ other adviser;

5. $59.4 \%$ financial adviser; and

6. $45.6 \%$ health or welfare adviser.

Clearly legal advisers mainly gave legal assistance (92\% of the time); although financial advisers (including accountants) did provide legal help in nearly $60 \%$ of the cases when they were consulted about a legal problem. This is despite the fact that some of this advice could be considered legal advice, which accountants are not permitted to provide for a fee. Unfortunately, it is not clear from the LAW Survey what the legal advice actually entailed - was it broad advice with a referral to seek advice from a lawyer, or was it something more? However, what is clear is that non-lawyers (in all their shapes and sizes) appear to be an important first point of contact when Australians are faced with a legal problem.

Part of the reluctance to seek legal advice from a lawyer could be the perception of cost, as this was considered a barrier for between $20-27 \%$ of participants, whereas for non-lawyers cost was rarely reported as a barrier in seeking advice (0-5\%). ${ }^{106}$

This high prevalence of non-lawyer intermediaries assisting with legal problems or providing advice is supported by other research, especially when considering business issues. For example, a 2016 study by Rutley et al found that in terms of setting up an Australian small business the sources of advice (in descending) order were: informal sources (such as previous experience, friends, family, google, online forums, other businesses, business partner, mentor) (41\%); accountants $(25 \%)$; business and industry associations (13\%); government agencies (6\%); lawyers (3\%); and the Australian Taxation Office (ATO) (1\%). ${ }^{107}$ Of concern is that just over a quarter $(28 \%)$ of persons setting up a business specified that no advice or information was sought at all. This is similar to the LAW Survey that found approximately one-third of participants did not seek advice when confronted with a legal problem. ${ }^{108}$

The Rutley et al survey indicated that the largest source of formal advice in starting a small business was from an accountant (25\%), with advice from a lawyer only sought in $3 \%$ of situations. ${ }^{109}$ This re-enforces that non-lawyer intermediaries are important conduits for advice. The role of accountants is even greater when small businesses seek advice about tax law, as an accountant is the first mentioned adviser $80 \%$ of the time. ${ }^{110}$

The reasoning for seeking advice from accountants and other tax professionals was "driven by very positive perceptions of their approachability, capability, accessibility, knowledge, trustworthiness, and reliability - as well as their familiarity with the ATO". ${ }^{111}$ It appears that there is a perception that accountants have the ability to give more holistic advice:

[Accountants] are perceived to offer more personal and specific information and advice because they are attuned to the specifics of an individual's business and the broader context of their business (e.g. history,

\footnotetext{
${ }^{105}$ Coumarelos et al, n 10, 128-129.

${ }^{106}$ Coumarelos et al, n 10, xvix.

${ }^{107}$ R Rutley, S Elliott and R Tatarynowicz, ATO - Small Business Engagement Report (TNS, 2016) 30-31.

${ }^{108}$ Coumarelos et al, n 10, xvi.

${ }^{109}$ Rutley, Elliott and Tatarynowicz, n 107.

${ }^{110}$ Rutley, Elliott and Tatarynowicz, n 107, 36-37.

${ }^{111}$ Rutley, Elliott and Tatarynowicz, n 107, 7.
} 
future plans, personal/family issues), allowing them to offer a more holistic perspective and tailored advice. ${ }^{112}$

Accountants tend to be involved at critical life stages in the business and they are seen as offering "trust, accountability and expertise". ${ }^{113}$ Early experiences with accountants mean that they become "embedded in the business's operation from early on, becoming a top of mind source for information or advice throughout the life of the business". ${ }^{114}$

An earlier Australian study into entrepreneurs supports the dominate role of accountants as advisers, as chartered accountants were found to be the most important type of paid consultant. ${ }^{115}$ This was re-enforced by the fact that $46 \%$ of firms had retained an accountant, whereas only $17 \%$ had retained a lawyer. ${ }^{116}$

Studies from the UK also demonstrate that accountants have a large and active role in providing advice about which business structure to utilise. In the early 1990s, Hicks et al sought to investigate why small businesses chose to incorporate. The role of accountants in assisting with incorporation was found to be great, as $70 \%$ of corporations were formed by accountants, $13 \%$ by company registration agents and only $12 \%$ by lawyers. ${ }^{117}$ Also, even though formal advice occurred in only approximately one-third (36\%) of cases, $97 \%$ of this advice was from accountants, with the remaining 3\% from lawyers. ${ }^{118}$ Although, when it came to general partnerships, lawyers had a more prominent role, with $85 \%$ of partnerships drawn up by a lawyer and $15 \%$ by an accountant. ${ }^{119}$ The difference between corporations and general partnerships may have to do with reforms that make setting up a corporation relatively easy, so that no legal qualification is required to purchase a corporate shell. For sole traders, when formal advice was obtained 50\% was from accountants and 30\% from lawyers. ${ }^{120}$ Consequently, it appears that depending upon the business structure chosen the role of the lawyer may increase, but evidently the accountant's role is dominate.

Another UK study found that the three most satisfactory sources of business structure advice were accountants (45.6 index score), business colleges (15.6) and lawyers (8.3). ${ }^{121}$ Similar to Rutley et al, Hicks et al concluded that the reason accountants were so heavily involved in business structure advice was due to "the close involvement of accountants with small business, and their detailed knowledge of the financial and tax affairs of their clients". ${ }^{122}$

A further aspect could be that lawyers may be unable to fully appreciate how their legal advice affects businesses. This could explain the major role of accountants rather than lawyers when business clients are faced with legal problems, as accountants are seen as having intimate knowledge of the business and the owner's goals - which thereby enhances their advice. Recently, it was reported that due

\footnotetext{
${ }^{112}$ Rutley, Elliott and Tatarynowicz, n 107, 7.

${ }^{113}$ Rutley, Elliott and Tatarynowicz, n 107, 30.

${ }^{114}$ Rutley, Elliott and Tatarynowicz, n 107, 30.

${ }^{115}$ P Davidsson, and S Gordon, "Comprehensive Australian Study of Entrepreneurial Emergence (CAUSEE): Design, Data Collection and Descriptive Results" in K Hindle and K Klyver (eds), Handbook of Research on New Venture Creation (Edward Elgar, 2011) 24.

${ }^{116}$ Davidsson, and Gordon, n 115, 24.

${ }^{117}$ A Hicks, R Drury and J Smallcombe, "Alternative Company Structures for the Small Business" in ACCA Research Report No 42 (Certified Accountants Educational Trust, 1995) 16.

${ }^{118}$ Hicks, Drury and Smallcombe, n 117, 16.

${ }^{119}$ Hicks, Drury and Smallcombe, n 117, 23.

${ }^{120}$ Hicks, Drury and Smallcombe, n 117, 23.

${ }^{121}$ A Southern and J Meyrick, "Owner-Managed Business and Their Tax: An Interim Report on the Views of Small Businesses" (Houses of Parliament, 2004) 10.

${ }^{122}$ Hicks, Drury and Smallcombe, n 117, 28.
} 
to the perception of a lack of business acumen law students felt ill-prepared to undertake commercial law courses compared to business students. ${ }^{123}$

Research from the US has demonstrated that those who sought professional advice in relation to which legal business structure to use exhibited greater confidence compared to those who did not seek advice in relation to protecting their personal assets and assisting their business' profitability. ${ }^{124}$

What these studies demonstrate is that when Australians are faced with a legal problem they may not seek advice at all, but when they do the role of non-lawyer intermediaries can be large. Further, in the areas of business legal issues such as structure and tax law advice the role of accountants can be larger than lawyers. This means that these non-lawyer intermediaries could be seen as important conduits to improving the legal literacy of the population, especially in relation to business operations. It is therefore productive to ensure the legal literacy of these non-lawyer intermediaries so they are better positioned to assist and direct people as a first point of contact for a legal problem.

\section{REFLections of Non-LAWyers' ROLE}

The studies referred to above illustrate that non-lawyer intermediaries appear to be an important first point of contact when people are faced with a legal problem, and accountants can have a prominent role when it comes to business. This is not a particularly new phenomenon, as Schuler and KadirgamarRajasingham observed that "the community based paralegal is emerging as an important means to make the law accessible to the grassroots". ${ }^{25}$ This does not mean the lawyer does not have a role, but the "emphasis is different". ${ }^{26}$ In this way, the use of non-lawyer intermediaries should not be perceived as a threat by lawyers, but instead as a potential benefit playing the role of "gateways to legal services". ${ }^{127}$

The legal advice sector is facing major changes, including automated systems that may undertake the role of lawyers, such as Blockchains for contract formations and online dispute resolutions that can harness artificial intelligence to assist in the mediation of legal issues. ${ }^{128}$ These changes have also led some individuals in the legal profession to work outside large firms by creating virtual networked firms. ${ }^{129}$ Beaton and Farrow have highlighted that the new reality of the legal profession is that massive information asymmetries will diminish and thereby reduce lawyers' monopoly on legal advice. ${ }^{130}$ The legal profession itself has started to reflect on the disruption it faces, as well as other professions, with the emergence of listed firms, multidisciplinary practices and virtual law firms. ${ }^{131}$ Beaton and Farrow have predicted that those multidisciplinary legal firms that are part of the Big Four accounting firms will move from their mid-market focus to higher value work in the future. ${ }^{132}$ Consequently, it is important to reflect upon the future of legal literacy and its role beyond lawyers as it appears that non-lawyer intermediaries do have and will continue to have an important role in the legal literacy of the public.

\footnotetext{
${ }^{123}$ H Zillmann and C Newport, "Adrift in a Sea of Revenue Law and Regulation Without a Proper Paddle" (Presentation at the 29th Australasian Tax Teachers Association Conference, Masteron, Victoria University of Wellington, 2017).

${ }^{124}$ G Hertz, F Beasley and R White, "Selecting a Legal Structure: Revisiting the Strategic Issues and Views of Small and Micro Business Owners" (2009) 20(1) Journal of Small Business Strategy 81. Unfortunately this study did not distinguish between advice sought from accountants and lawyers, and instead aggregated them together.

${ }^{125}$ Schuler and Kadirgamar-Rajasingham, n 37, 9.

${ }^{126}$ Schuler and Kadirgamar-Rajasingham, n 37, 9.

${ }^{127}$ Coumarelos et al, n 10, xxii.

${ }^{128}$ M Legg, "The Future of the Legal Profession" (2016) 2 UNSW Law Alumni News 6.

${ }^{129}$ R Dawson, "The Future of Associations" in J Guthrie, E Evans and R Burritt (eds), Relevance and Professional Associations in 2026 (RMIT and Chartered Accountants ANZ, 2016) 25.

${ }^{130}$ G Beaton and B Farrow, "The Future of the Legal Profession" in Guthrie, Evans and Burritt, n 129.

${ }^{131}$ Legg, n 128.

${ }^{132}$ Beaton and Farrow, n 130, 48-54.
} 
It has been suggested that these non-legal intermediaries could provide people with a single, wellresourced contact point for legal referral, and include such things as a generalist legal advice service or legal triage service. ${ }^{133}$ While it is acknowledged that technically these non-lawyer intermediaries should not be paid for legal advice, the fact remains that many people will call upon them for assistance. In light of this, the legal literacy of these intermediaries should be considered, as their legal knowledge must include understanding their limitations, as well as how to refer people to further resources for assistance. This realisation could affect how legal literacy programs are targeted - ie rather than targeting the end user (the individual), targeting the intermediaries may be more effective, especially if they have established trust. This realisation has led to legal education programs that target community workers, as they can be a key pathway between disadvantaged people and legal assistance services. ${ }^{134}$ For example, it was found that more than half (51.5\%) of community legal education events of Legal Aid New South Wales were for community workers and other professionals only. ${ }^{135}$ Lawyers are coming to appreciate how these intermediaries can be an effective outreach advice service. ${ }^{136}$

Further, focusing on the legal literacy of intermediaries takes into account that direct legal literacy education is "not a realistic aim for some users, including people with low legal capability, or those who are facing complex issues at different points in time". ${ }^{137}$ In terms of business, accountants and industry bodies appear to play a major role in assisting business people's legal literacy. Consequently, it is important to ensure that these non-lawyer intermediaries are adequately equipped. It should be acknowledged that there does appear to be overall satisfaction with the advice of non-lawyer intermediaries. For example, the LAW Survey found that intermediaries were rated as very or fairly helpful in assisting with legal problems (industry associations $73 \%$; financial advisers $82.7 \%$ ), which is very similar to the level of satisfaction of advice sought from private lawyers $(80.8 \%){ }^{138}$

Nevertheless, various authors have expressed concern about the legal literacy of accountants. For example, in 2013, in outlining current issues with the Administrative Appeals Tribunal's functioning in tax disputes, the Hon Duncan Kerr Chev LH laminated that many representatives are not lawyers and instead are often accountants from small practices with limited knowledge of process and few resources to properly advise clients. ${ }^{139}$ Recent evidence from Walpole and Tran-Nam re-enforces these concerns about accountants in the Tribunal, especially in relation to the rules of evidence. ${ }^{140}$

The 2009 research project funded by the Australian Learning and Teaching Council entitled "Accounting for the Future: More than Numbers" considered the skill set for professional accounting graduates, ${ }^{141}$ and found a stated need for the ongoing training of accounting graduates about the law relating to superannuation, tax, trusts and companies. ${ }^{142}$

\footnotetext{
${ }^{133}$ Coumarelos et al, n 10, xxii.

${ }^{134}$ Coumarelos et al, n 10.

${ }^{135}$ S Forell and HM McDonald, Community Legal Education and Information at Legal Aid NSW: Activities, Costs and Future Planning (Law and Justice Foundation of NSW, 2015).

${ }^{136}$ Forell and McDonald, n 16, 7.

${ }^{137}$ Forell and McDonald, n 16, 8.

${ }^{138}$ Coumarelos et al, n 10, 124-125.

${ }^{139}$ D Kerr Chev, "Tax Dispute Resolution: The AAT Perspective" (Speech given to the Tax Bar Association of Victoria, 4 June 2013) $<$ http://www.aat.gov.au/about-the-aat/engagement/speeches-and-papers/the-honourable-justice-duncan-kerr-chev-lh-presid/ tax-dispute-resolution-the-aat-perspective $>$.

${ }^{140}$ B Tran-Nam and M Walpole, "Effective Access to Independent Tax Dispute Resolution in Australia: The Tax Adviser's Perspective" (Presentation at the 29th Australasian Tax Teachers Association Conference, Masteron, Victoria University of Wellington, 2017).

${ }^{141}$ P Hancock et al, Accounting for the Future: More than Numbers (Vol. 1: Final Report) (Australian Learning and Teaching Council, 2009).

${ }^{142}$ Hancock et al, n 141, 54, 58.
} 
Accountants' education regarding the law of trusts has also been raised as a potential deficiency in the Australian university accounting curriculum, given the increased utilisation of trusts for business. ${ }^{143}$ Such concerns have been reiterated by Hor in regards to accountants and other service providers in dealing with governance documents involving trusts, highlighting that accountants may not have "the expertise or experience to properly understand the trust deeds that they are reviewing". ${ }^{144}$ More recently concerns have been raised about accountants' SMSF education, which has resulted in legislative reforms requiring them to obtain a licence once they have been able to demonstrate appropriate knowledge levels. ${ }^{145}$ Such perceived low levels of legal literacy of accountants have led to the raising of the legal knowledge required by the Tax Practitioner Board for accountants who wish to be a registered as a tax agent. ${ }^{146}$ These commercial and tax law requirements are generally beyond the normal accreditation requirements of other accounting professional bodies. ${ }^{147}$

It is argued that the role of non-lawyer intermediaries in providing legal advice for business has the following implications for their legal literacy: first, awareness of the relevance of legal knowledge to their future careers as business advisors; secondly, what areas to teach; and thirdly, communication skills. Each of these is discussed below.

\section{Awareness}

It is argued that the tertiary curriculum for accountants includes the reality that accountants are likely to be the trusted business advisors for their clients, and as such they are likely to be the first point of contact when their clients are faced with a legal problem. This awareness is critical, as it emphasises to accounting graduates the importance of their law courses beyond their accounting degrees. Also, it raises awareness about the limitations of their legal knowledge, and how they can assist their clients in accessing appropriate legal advice. In this way, accountants are an important conduit between clients and lawyers in seeking to assist clients with their legal problems. This includes helping clients to initially identify that they may have a legal problem, that they need to seek assistance and where to find that assistance. This awareness requires a critical assessment of the areas taught to accounting students.

\section{Areas}

How to improve the legal literacy and topic coverage for non-lawyer intermediaries, such as accountants, can be a vexed question; it needs to be acknowledged that they are not training to be lawyers and that their required knowledge is different. This means to be effective "the body of legal knowledge must be critically analysed and possibly re-structured if it's to be an effective component" of the education curriculum. ${ }^{148}$ This can involve the difficult task of trying to persuade program/degree administrators of the importance of legal knowledge in professional degrees - especially when there is already a crowded curriculum. However, it is essential that this reflection occurs, especially given that professions are under pressure due to technological disruptions.

While it may be tempting to design a law course for non-lawyer intermediaries around key areas of law, such as contract or the law of torts, a number of authors have argued that what must be considered are the business advisers' "relationships" and the legal principles that govern them. Such a teaching gestalt would involve the discussion of multiple areas of the law that could apply to influence such relationships.

\footnotetext{
${ }^{143}$ B Freudenberg and D Boccabella, "Changing Use of Business Structures: Have University Business Law Teachers Failed to Reflect This in Their Teaching?” (2014) 9(1) Journal of the Australasian Tax Teachers Association 180.

${ }^{144}$ B Hor, "Reviewing Family Trust Deeds — It's Not Just About Tax!” (2012) Aug Taxation in Australia 90, 90.

${ }^{145}$ B Freudenberg and D Boccabella, "Can Stakeholders be Satisfied with Accountants' Education to Act as Advisors to SelfManaged Superannuation Funds" (2016) 2(1) Financial Planning Research Journal 36.

${ }^{146}$ For the educational requirements of Tax Agents, see <http://www.tpb.gov.au/>.

${ }^{147}$ Freudenberg and Boccabella, n 143.

${ }^{148}$ Cartan and Vilkinas, n 7, 246.
} 
For example, Cartan and Vilkinas outlined the 10 major relationships that a manager of a business is likely to encounter, ${ }^{149}$ including relationships with: customers; suppliers; employees; investors; the legal profession; creditors; government; competitors; the public; and the organisation itself (see Fig 1). Accountants need to be aware of how these relationships relate to their clients so they can seek to assist and direct them in regards to their legal obligations.

FIGURE 1: Law for Managers Framework

LAW FOR MANAGERS FRAMEWORK

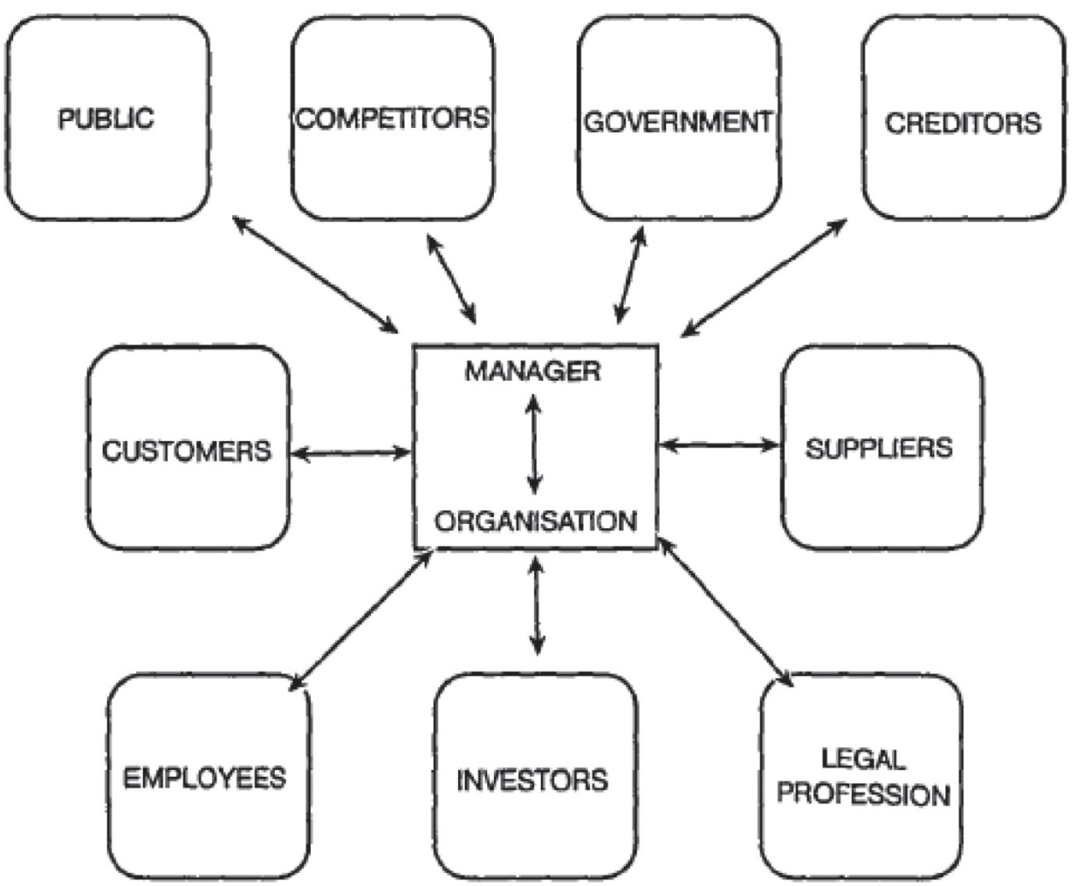

Source: G Cartan and T Vilkinas, "Legal Literacy for Managers: The Role of the Educator" (1990) 24(3) The Law Teacher $246,252$.

However, it is critical not only to teach these core areas but also to prepare graduates in "using" the information that they have found. Universities have placed much emphasis on finding information, but little guidance or practice in using it. ${ }^{150}$ Part of this education is not just the content knowledge, but also the "teaching of problem-solving techniques", as this can be an essential component of legal literacy. ${ }^{151}$

Additionally, it is critical that the curriculum reflect current commercial reality. For example, concerns have been raised about the curriculum lag of Australian accounting degrees in respect of teaching about the law of business structures. In a curriculum audit of Australian accounting degrees it was identified that while trusts and SMSFs have become prevalent for Australian businesses, the information and the law relating to them is largely absent from core courses. ${ }^{152}$ This teaching of law to

\footnotetext{
${ }^{149}$ Cartan and Vilkinas, n 7, 252.

${ }^{150}$ B Freudenberg, "Learning to Learn: Business Professionals' Perceptions of Information Literacy" [2008] ConTax Student e-Newsletter, Taxation Institute of Australia 16.

${ }^{151}$ S Valentine, "Legal Research as a Fundamental Skill: A Lifeboat for Students and Law Schools" (2009) 39(2) University of Baltimore Law Review 175, 201.

${ }^{152}$ Freudenberg and Boccabella, n 143.
} 
non-lawyer intermediaries needs to include the limitations of their ability to advise on such legal matters, and where they can seek further advice.

\section{Communication}

Being a good communicator and understanding the market have been identified as critical attributes for future professionals, especially as they are likely to be operating across a number of disciplinary boundaries ${ }^{153}$ When it comes to non-lawyer intermediaries assisting with legal problems communication is a key skill.

Communication needs to be considered both in terms of accountants and their clients, as well as between accountants and lawyers. To achieve greater legal literacy effective communication is important. Coumarelos et al reflect that perceptions of not receiving clear and adequate advice may sometimes reflect the recipient's low capacity to understand legal information, rather than poorly framed advice. ${ }^{154}$ Alternatively, it could reflect the advice giver's inability to pitch the advice to the audience, or their unawareness of the person's level of legal literacy. Effective communication can in part rely on being aware of the legal literacy of the other party to ensure that areas of potential misunderstanding are identified and addressed.

Research has expressed concern about the communication between lawyers and their business clients. Elliott and Wolfe have argued that the lawyer-client dynamic needs investigation. ${ }^{155}$ Klayman and Nesser highlighted how the legal literacy of business students and law students should be different and take into account communication between both professionals. ${ }^{156}$

Part of this difficulty in communicating may relate to business peoples' level of legal literacy and perhaps unrealistic expectations about what the legal system can achieve. This could include the scope of legal advice and how it cannot fix fundamental business problems, such as under-capitalisation or management issues. ${ }^{157}$

Overall, it is suggested that in designing legal education for non-lawyers it is essential to reflect on the relationships they are likely to encounter, and then consider the legal principles that guide these. This needs to be highly contextualised, and should include how to communicate with legal advisers and clients who may come to business advisers when faced with a legal problem.

\section{FUtURE RESEARCH}

This article has raised some insights and reflections about the importance of legal literacy for non-lawyer intermediaries, especially business advisers. However, to progress this further there are a number of areas for future research. Such research is important, as demonstrated by Forell and McDonald's lamentation regarding the "paucity of evidence" about whether legal education initiatives work. ${ }^{158}$

It is essential that assessments of education programs to assist with legal literacy consider what is effective for the education of non-lawyers intermediaries. It is also important to address what Cassidy and Pitsula identified as the mistake of "lumping legal information with education, on the assumption that information sharing was education", ${ }^{159}$ and to determine the level of legal literacy (and capability) required of business advisers. Such principles need to be informed by sound research within a jurisdictional context.

\footnotetext{
${ }^{153}$ S Davidson, "Future Tensions in Professional Associations" in Guthrie, Evans and Burritt, n 129.

${ }^{154}$ Coumarelos et al, n 10, 213.

${ }^{155}$ William and Wolfe, $\mathrm{n} 6$.

${ }^{156}$ E Klayman and K Nesser, "Eliminating the Disparity Between the Business Person's Needs and What is Taught in the Basic Business Law Course" (1984) 22 American Business Law Journal 41, 58.

${ }^{157}$ William and Wolfe, n 6, 166.

${ }^{158}$ Forell and McDonald, n 16, 2.

${ }^{159}$ Cassidy and Pitsula, n 29, 119.
} 
Future research could determine what level of "business" legal literacy is required for operators, advisers and agencies. A valuable insight could be to survey past business graduates as to the areas of legal literacy that are of greatest importance to current practices. For example, a survey of past business school graduates could be conducted like that of Klayman and Nesser in the US. ${ }^{160}$ Such research could also explore possible best practices in terms of teaching law to these business advisers. ${ }^{161}$

Further research could consider sources of legal literacy for business advisers, as well as the best communication practices between business advisers and clients, as well as between lawyers and business advisers. Further, a LAW Survey with a specific focus on business legal issues could be conducted to ascertain where people seek advice from, and how effective they find it in addressing their businessrelated legal problems.

\section{CONCLUSION}

The world of business is a critical component of modern life, providing many with the opportunities to progress their position and enhance social inclusion. However, it is underpinned and supported by an array of legal principles. In this context legal literacy is an important attribute to ensure that these potential economic benefits can be fully realised.

When confronted with legal problems evidence demonstrates that many Australians do nothing. However, for those that do seek advice, only a small fraction seek it from an actual lawyer, with many using non-lawyer intermediaries as an initial adviser. In particular, business advisers, such as accountants, are an important first source of advice, even if the advice sought is not technically about the law itself. The preference for advisers from this sector can be attributed to their intimate knowledge of the person, their relationships and business circumstances. Consequently, non-lawyer business advisers can be an important intermediary for assisting people with their legal problems. In this way, these intermediaries play a role in improving the legal literacy of the population in general.

While there appears to be overall satisfaction with advice from non-lawyer intermediaries, concerns have been raised about the adequacy of their legal literacy. It has been argued that a key issue is awareness, as business advisors need to be acutely aware that their clients are likely to call upon them when they are faced with a legal problem. Further, context and the consideration of the commercial relationships likely to be encountered could be an important gestalt in the design and delivery of legal literacy for business advisers, as well as how they seek advice from and communicate with lawyers.

It is only with further research and development that legal literacy will be improved and enhanced within this important component of the legal advice framework. This is not to suggest that the legal literacy of citizens is not important, but it is critical to recognise that many people seek help from non-lawyers when faced with a legal problem. It is essential that these non-lawyer intermediaries have sufficient legal literacy to assist them in their role and is reflective of current practices. Addressing the legal literacy of these important intermediaries can assist in ensuring greater civil engagement for all in the future and that legal literacy is not just for lawyers.

\footnotetext{
${ }^{160}$ Klayman and Nesser, $\mathrm{n}$ 156, 47. The study found the 10 most valuable topics, which (in order) were: contract formation; business organisations; scope of regulatory power; negotiable instruments; debtor-creditor relations; sale of goods; business ethics; antitrust; real property; and product safety and liability.

${ }^{161}$ B Freudenberg, "Show Me the Evidence: How the Scholarship of Learning and Teaching is Critical for Modern Academics" (2012) 7(1) Journal of the Australasian Tax Teachers Association 171.
} 